\title{
Forensic dental expertise
}

\author{
El peritaje odontológico forense
}

\author{
Agustín Tiol-Carrillo*
}

\begin{abstract}
When a patient arrives at a dental office or hospital in order to receive treatment and there is some unconformity with respect to dental service provided, the patient will be able to resort to different authorities and judicial organisms to vent his complaints on events that took place and promote claims or complaints before competent authorities such as Comision Nacional de Arbitraje Medico (CONAMED) (National Commission for Medical Arbitrage), Comision Nacional de Derechos Humanos (CNDH) (National Commission for Human Rights) attorney general, as well as criminal or civil jurisdiction.

It is necessary for the dentist to be knowledgeable with the different circumstances which might arise once the unsatisfied patient has resorted to any of the aforementioned judiciary organs or institutions. Not all the complaints presented by a patient merit the initiation of a penal procedure, only those described in a Penal Code, and more precisely in some section of "Professional Responsibility" should be taken into account.According to article 7, Chapter 1 of the Federal Penal Code, offense is any action or omission penalized by penal law. ${ }^{1}$

Nevertheless, the most common cause for patient dissatisfaction is having been inflicted damage in oraldental health that was not present before treatment. There are several actions or omissions that a dentist can perform and which can be the motive for suits demands or unconformities. We hereby offer a list:
\end{abstract}

\section{GUILT AND MALICE}

Any action or omission taking place in the practice of the profession can be consummated maliciously or culpably. According to the Penal Federal Code in its Chapter "General Rules on Offense (offense crime) and Responsibility, Article 9» a subject acts maliciously when knowing the penal type elements or foreseeing as possible the typical result, wants or accepts the accomplishment of the fact. A subject acts culpably when he produces a typical result which he did not foresee (although it was foreseeable) or trusting that it would not take place».1,2
In other words, deceit is effected when although knowing the judicial consequences of a certain action, it is decided to perform it in an autonomous and voluntary manner, and guilt takes place when, without desiring it, an unexpected result is obtained, and this result is legally typified as an offence.

\section{MEDICAL MALPRACTICE}

Also called «poor praxis» or medical malpraxis, it takes place when a set of clinical and ethical errors chronologically take place during dental practice, independently of the fact that the dentist might not count with minimal necessary knowledge to provide a solution to the condition of the patient. ${ }^{2}$ For instance, a dentist exerts «poor praxis» when he does not count with minimal equipment and material necessary to provide dental care, when he foregoes a patient's treatment without any justification, in cases when the dentist is offensive and arrogant to a patient, or when there is absence of effective communication between dentist and patient.

It would be relevant to highlight that the clinical part of a «poor praxis» does not only consist on performing low quality procedures, lack of dentist's knowledge to be able to establish accurate diagnosis, or dentist's inability to clearly and effectively expose postoperative indications of some procedure. ${ }^{2,3}$ When as a consequence of this medical malpraxis the health professional causes damage in the patient which he did not suffer before visiting him, it is called iatrogenia. ${ }^{4}$

\section{INEXPERIENCE}

Lack of skill can be described as care provided by non-qualified personnel who lack skills and minimum knowledge necessary to solve a patient's oral and dental health problem. A dentist acts with lack of skill

\footnotetext{
* Full time professor. Metropolitan Autonomous University, Xochimilco Campus.
}

This article can be read in its full version in the following page: http://www.medigraphic.com/facultadodontologiaunam 
when, lacking the specialist's degree, he conducts risky procedures even though he is aware of the negative consequences that might arise.

\section{NEGLIGENCE}

In these cases, the dentist counts with full knowledge and sufficient skill to solve the patient's affliction, but due to poor ethics and reasons such as carelessness, forgetfulness or indifference, he voluntarily decides not to perform pertinent actions, although treatment prognosis might be affected by it (Figure 1). For instance, when a dentist voluntarily decides to undertake operative dentistry or endodontic treatment with absence of total isolation with a rubber dam, he is acting negligently. Likewise, it is considered a negligent action when the dentist underestimates a real emergency (such as abscess or odontogenic facial cellulite) and voluntarily decides not to treat the patient or to refer him to the pertinent specialist.

\section{IMPRUDENCE}

Imprudence occurs when the dental personnel acts with excess confidence, not foreseeing negative consequences that might arise during the performance

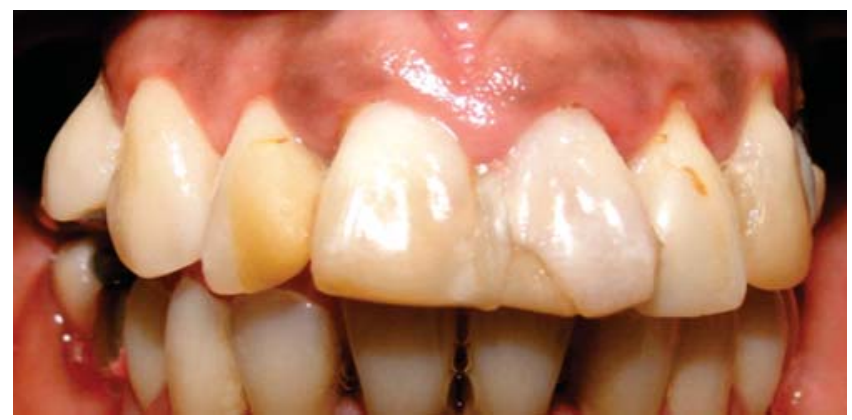

Figure 1. The dentist voluntarily performed maladjusted restorations which prevented suitable oral hygiene. of a given procedure. For instance, this would be the case when a dentist intends to conduct a root canal treatment when he is knowingly aware that files to be used in the procedure are in poor state or weakened by use; he knows perfectly well that these files can fracture within the canals, but nevertheless, he decides to use them. Figure 2 ( $A$ and $B$ ) shows the case of a patient treated with bi-phosphonates, a deficient clinical history of this patient was taken, due to dentist lack of observance and imprudence, the dentist performed multiple extractions and culpably caused maxillary and mandibular osteonecrosis.

\section{FAILURE TO COMPLY}

This is culpably configured when the professional does not grant sufficient attention to a given fact and thus involuntarily causes damage to the patient's health. A dentist commits failure to comply when he performs an inappropriate treatment due to inattention to his professional responsibility An example of this would be friction burns in the corner of the lips (labial commissure) during a dental extraction by dissection of a lower third molar.

Based on the aforementioned explained facts, when a dissatisfied patient resorts to a competent institution to inform about his complaint, an expert procedure will be initiated; this will begin with a request from the Public Prosecutor or from the National Commission of Medical Arbitrage, so as to analyze the case and impart a fair solution for both parties (patient-dentist).

All dental health professionals must be aware of the fact that there are different circumstances which might general false imputations, in cases when the dentist has not incurred in real blame. For example, when the patient consciously decides not to follow indications given by the dentist, then, complications arise as a consequence of this neglect, or when the patient additionally omits prescribed pharmacological therapies, demands unnecessary treatment in teeth
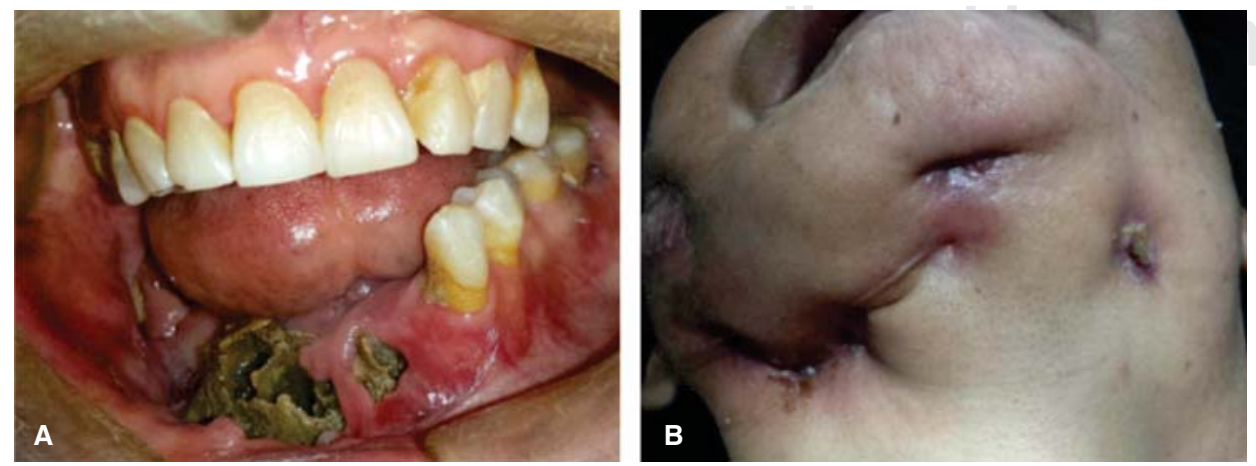

Figure 2.

Patient afflicted with maxillary and mandibular osteonecrosis after multiple extractions. The fact that the patient was undergoing biphosphonate treatment was not taken into consideration (Courtesy of CMF Carmina Peña Martinez). 
that do not require therapy, or when the patient voluntarily decides not to continue with treatment.

\section{MEDICAL CIVIL RESPONSIBILITY}

According to items described in the Federal Civil Code, article 1910, it is stated that if a subject acts illicitly or contravenes good morals, and that as a result of this, damage is caused, such damage must be repaired. ${ }^{5}$ For an action to generate proper responsibility the following characteristics must be met: that the action performed be illicit and that said action has caused damage and there is a causative link between damage and fact. ${ }^{4}$ Among actions that might incriminate a dentist during the practice of his profession, the only one that is accepted in most set of laws is the fact of acting with neglect and failure to comply. The Mexican Official Norms (Normas Oficiales Mexicanas NOM) on compulsory observance and administration must be applied in all Mexican territory; ${ }^{6}$ in cases when the dentist incurs in judicial anomalies, it will be ascertained that said dentist acted in concordance to the aforementioned. It is important to point out that civil suits will never cause loss of freedom as legitimate sentence; there are several administrative sanctions which might be imposed to the health professional, these are described in Table I.

\section{MEDICAL PENAL RESPONSIBILITY}

The Federal Penal Code in its article number 228 indicates that professionals, artists or technicians and their auxiliary personnel will be responsible for offenses committed during the exercise of their profession; it warns that they will be compelled to repair damage caused by their actions, and in the case of recurrence, temporary or definite suspension of their professional activity might be imposed. ${ }^{1}$ Thus, in order for a given action effected by a dentist to be typified, that is to say, for that action to be described in the Penal Code as an offense, it must possess certain specific characteristics which in Law Practice are called elements of the offense (Table II).

\section{FORENSIC DENTISTRY EXPERTISE PROCEDURES}

In Mexico, the authority which most often mediates in this type of situations is the Medical Arbitrage National Commission (Comision Nacional de Arbitraje Medico), this is a government public institution which offers agreements to disputes of patients and health service operators, this institution additionally collaborates with judiciary authorities.

According to what is described in Article 17 of the Mexican Constitution, any controversy between two

Table I. Sanctions that might be imposed on a dentist in administrative/civil trials.

Financial sanction/fine

Subpoena

Employment or work suspension

Dismissal from office
- Is determined based on the severity of the damage and prejudice caused by the health professional

- Authorities will publicly or privately give notice to the professional, inviting him not to recur in the same irregularity, warning him that if he so does he will receive a more severe sanction

- Temporary interruption of the professional activity for the time deemed necessary by the authorities

- Is the permanent work disqualification or removal of all rights and obligations of a health professional in his area

Table II. Elements of an offence (crime).

\begin{tabular}{|c|c|}
\hline Element of offence & 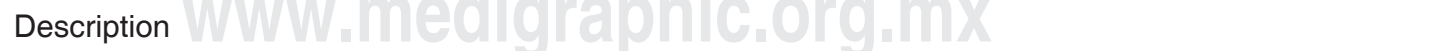 \\
\hline Action or omission & - The dentist does or fails to do something that causes direct damage to the patient \\
\hline Type casting & - The conduct undertaken by the dentist is explicitly described in the Penal Code \\
\hline Anti juridicity & - When the conduct undertaken by the dentist goes against that which is accepted by law \\
\hline Imputability & $\begin{array}{l}\text { - The capacity of the dentist to want and understand the anti-juridicity of the conduct, and deciding to } \\
\text { realize it in spite of it }\end{array}$ \\
\hline Culpability & $\begin{array}{l}\text { - Consummated behavior which causes unexpected results due to the fact of not foreseeing what was } \\
\text { foreseeable }\end{array}$ \\
\hline $\begin{array}{l}\text { Punishability } \\
\text { (criminal liability) }\end{array}$ & $\begin{array}{l}\text { - The action committed by the dentists has the characteristic of being punished by competent } \\
\text { authorities }\end{array}$ \\
\hline
\end{tabular}


parties must be solved through expedite tribunals or authorities. ${ }^{7}$ The State grants CONAMED authorization to mediate in this type of conflict of interest, but it cannot absolutely substitute justice-imparting tribunals. When a case is established, CONAMED can act in different ways. The so-called friendly composition arbitrage consists on granting moral authority to a third party so that it analyzes occurred facts, reunite both parties in search of alternatives to try to reach a solution of the controversy without intervention of judiciary authority; consequentially, this resolution cannot be coercible, that is to say, accorded actions can be fulfilled or not fulfilled. If the patient continues in disagreement, he can then proceed to strict law arbitration, where the arbitrator, who is a recognized and accepted legal individual, will solve the case according to his consideration, or else according to the law. In the first evidentiary stage, all proof from dentist must be provided to later unburden judicial evidence. In this case evidence is all documentation inherent to the case, such as original clinical file, medical history, extra and intra oral exploration, odontograms, X-rays, informed consent or notes of progress. Evidence unburdening also includes testimonies of both parties and expertise intervention.

When this part is completed, a conclusion called judgment (ruling) will be emitted, which will be informed to both the patient and the dentist. In order to be legally valid, the judgment must be sent to appropriate expedite tribunals which will ascertain their authenticity and later order its execution, thus providing a solution to the controversy. ${ }^{8}$ If the ruling is In favor of the patient he will have the right of not paying the fee he had previously agreed upon with the dentist before the conflict, Moreover, the dentists deemed responsible will have to pay compensation for damage caused to the patient. On the other hand, if the ruling is in favor of the dentist he will be able to freely charge the fees he previously agreed upon, as well as expenses incurred during the trial and compensation to damage caused to his professional prestige. ${ }^{9}$

With respect to the judiciary sphere, the dissatisfied patient will be able to present his complaint with the public prosecutor, and this will initiate penal procedures. As indicated in article 211 of the Codigo Nacional de Procedimientos Penales (CNPP) (National Code for Penal Procedures), penal procedure encompasses several procedural stages: initial research, complementary, intermediary or casepreparation research as well as the trial stage..$^{10}$ During the initial research stage, the complaint is effected, this can be defined as the mechanism by which a subject informs the competent authorities about the probable commission of an offence. ${ }^{11}$ Once this has taken place, a citation must be sent to the dentist to appear in front of the Public Prosecutor in subsequent days. At this stage of penal investigation, the dentist will we named «imputed party»; he will have the right to a defense attorney from the beginning of the procedure. According to what is stated in article 216 of the CNPP both the victim and the imputed party might request the execution of all investigative acts deemed useful to clarify the facts, the request cannot be prolonged for more than three days after the date in which the petition has been established (formulating the request). All collected proof elements must be protected by a chain of custody as indicated in article 227 of the CNNP. At the beginning of the initial audience, the control judge will assign a lawyer to the dentist (in case he did not count with one) and he will inform the dentist of the facts with which he is charged. Based on facts, the judge will decide whether the imputed party must be arraigned as cautionary measure, or whether he might remain free during the subsequent phases of the procedure. This will be the case as long as the imputed party attends all the hearings, the Public Ministry Attorney, can emit an arrest warrant or summons to appear in case it is deemed necessary.

The purpose of the intermediate stage is to present and admit proof in an oral (verbal) phase, and later in a written phase. According to CNPP stipulations, proof can be by confession, by public or private documents, expert opinions or witness declarations. Once the proofs are unburdened, the final stage will be reached, in this stage, the Judge will dictate sentence, and the procedure will be ruled by principles of publicity, immediacy, concentration, equality, continuity and contradiction.

All dentists must be aware of all actions or omissions which might cause patient unconformity during the practice of their profession, they must be aware of judicial consequences that might arise when these unconformities reach pertinent authorities. Likewise, dentists must try to avoid to the utmost performance of inadequate conduct which might cause untoward effects in the patients' health, since they might be sanctioned according to the severity of their behavior. All stomatologists must comply in all their professional actions with laws and regulations in force so as to avoid development of civil or penal litigations.

\section{REFERENCES}

1. Código Penal Federal, 2015.

2. García, Gl. Procedimiento pericial médico-forense. Normas que lo rigen y los derechos humanos. Cap. 3: "Procedimiento de investigación, detección y dictamen médico-legal por supuesta mala práctica médica". México, Ed. Porrúa. 2012. 
3. Cano VF, Cáceres NE, Díaz AE. Dispraxis. "Praxis, dispraxis médica y Derecho Penal". Instituto de Investigaciones jurídicas, Universidad Nacional Autónoma de México, $2^{\text {a }}$ ed. 2012.

4. Domínguez MJ, Sánchez BJ. Homenaje al maestro José Barroso Figueroa por el Colegio de profesores de Derecho Civil, Facultad de Derecho-UNAM. Capítulo 10. "Responsabilidad civil médica". México, 2014.

5. Código Civil Federal. 2015.

6. Diario Oficial de la Federación. 2016.

7. Constitución Política de los Estados Unidos Mexicanos (comentada). Décimo Octava Edición. Abril, 2012. Edit. Trillas.

8. Comisión Nacional de Arbitraje Médico [www.conamed.gob.mx]. "Modelo Mexicano de Arbitraje Médico" [Consultado el día 01 de Octubre 2015] Disponible en: http://www.conamed.gob.mx/ conocenos/modelo/Dimensiones\%20del\%20MAM1.pdf
9. Valle GA, Fernández-Varela MH. Arbitraje médico. Fundamentos teóricos y análisis de casos representativos. Cap.4 "Marco jurídico de la práctica médica”. México, Ed. Trillas, 2014.

10. Quintana VJ, Cabrera MA. Manual de procedimientos penales. Cap. 5 "Definición de proceso". México, Ed. Trillas, 2008.

11. Código (Único) Nacional de Procedimientos Penales. Ley nacional de mecanismos alternativos de solución de controversias en materia penal. Enero 2016. Editorial SISTA.

Mailing address:

Agustín Tiol-Carrillo

E-mail: agustintiolcarrillo@gmail.com 